\title{
Evaluation of antimalarial and antioxidant activities of the methanol seed extract of Adenanthera pavonina (Linn) in Plasmodium berghei infected mice
}

\author{
Aduragbenro D. A. Adedapo', Juliet N. Olayinka', Oyindamola O. Abiodun ${ }^{1,2}$, Ademola A. Oyagbemi', \\ Odunayo Azeez ${ }^{3}$, Adeolu A. Adedapo ${ }^{3}$, Adegoke A. Adeyemi ${ }^{4}$, Jones O. Moody ${ }^{4}$ \\ ${ }^{1}$ Department of Pharmacology and Therapeutics, College of Medicine, ${ }^{2}$ Malaria Research Laboratory of the Institute of Advanced Medical \\ Research and Training, (IMRAT), ${ }^{3}$ Department of Veterinary Physiology, Biochemistry and Pharmacology, ${ }^{4}$ Department of Pharmacognosy, \\ University of Ibadan, Ibadan, Nigeria
}

\section{A B S T R A C T}

Objectives: Malaria and oxidative stress are major health problems in the world in general. The goal of the study is to investigate the antimalarial and antioxidant activities of the methanol seed extract of Adenanthera pavonina linn (ADP) in Plasmodium berghei infected mice. Methods: Thirty five mice distributed into seven groups of five animals each were used in this study. Plasmodium berghei, was inoculated into Swiss albino mice intraperitoneally with an innoculum size of $1 \times 10^{7}$ on day zero (D0). The vehicle (1\% DMSO), ADP (100, 200, 400,600 and $800 \mathrm{mg} / \mathrm{kg}$ dose) or chloroquine $(10 \mathrm{mg} / \mathrm{kg}$ ) were thereafter administered from D0 - D3. At the end of the antimalarial studies, the blood samples from these animals were collected through cardiac puncture for biochemical assay. The effect of the ADP on the biomakers of oxidative stress was determined in infected mice. In addition in vitro antioxidant activities of ADP were assessed using the 1, 1-diphenyl-2-picrylhydrazyl (DPPH) based assay. Results: The percentage parasitemia decreased significantly in the parasitized treated group with the crude extract $(p<0.001)$ compared to the parasitized untreated control group. Also the crude extract, at a dose of $800 \mathrm{mg} / \mathrm{kg}$ exerted an antimalarial activity $(92.11 \%)$ higher than that of chloroquine $(88.73 \%)$. In the in vitro antioxidant studies, the extract had an $\mathrm{IC}_{50}>400 \mu \mathrm{g} / \mathrm{ml}$ which was significantly higher than the standard antioxidant drug, ascorbic acid $\left(1 \mathrm{C}_{50}=1.20 \mu \mathrm{g} / \mathrm{ml}\right)$. In the case of biochemical and in vivo assay, there was no statistical significant difference $(p>0.05$ ) in plasma total protein, malondialdehyde (MDA) and hydrogen peroxide $\left(\mathrm{H}_{2} \mathrm{O}_{2}\right)$ levels in all the treated groups compared to the parasite control group but, there was a statistical significant decrease ( $p<0.05$ ) in glutathione (GSH) levels at doses of 400 and $800 \mathrm{mg} / \mathrm{kg}$ compared to the parasitized untreated control group. Conclusions: Methanol seed extract of Adenanthera pavonina demonstrated a significant antimalarial activity but did not exert any antioxidant effect over the parasitized treated mice.
Access this article online Website:

http://nepjol.info/index.php/AJMS

\section{INTRODUCTION}

Malaria and oxidative stress are major health problems in the world in general. Malaria is a disease that is predominant in the tropics which is caused by protozoa of the genus plasmodium and transmitted from man to man by various species of the female mosquito. ${ }^{1,2}$ Recent reports suggest that generation of reactive oxygen species and associated oxidative stress play crucial role in the development of systemic complications in malaria. ${ }^{3}$ Malarial infection decreases the levels of antioxidant enzymes and other antioxidants such as catalase, glutathione (GSH) peroxidase, super-oxide dismutase, albumin, glutathione, ascorbate and plasma tocopherol. ${ }^{4}$ An antioxidant acts as a reducing agent that donates electrons to the free radicals. ${ }^{5}$ They are capable of deactivating or stabilizing free radicals before 
they attack cells. Recent developments in biomedicals point to the involvement of free radicals in many diseases. ${ }^{6}$ Free radicals attack the unsaturated fatty acids in the biomembranes resulting in membrane fluidity. ${ }^{7}$ For these reasons antioxidants are of interest for the treatment of many kinds of cellular degeneration. ${ }^{6}$

Adenanthera pavonina linn of the family Leguminosae and subfamily Momosoideae $e^{8}$, is a deciduous tree, 18-24 m tall, bole erect and it is $60 \mathrm{~cm}$ in diameter ${ }^{9,10}$ with pinnately compound leaves. Its common names are red sandal wood, coral bean tree, saga seed tree, red bead tree, rakta kambol, kokriki, olho-de-pavao and bois de condori, lopa. In the Carribean, the seeds are called circassian seeds. This deciduous tree has been widely naturalized in Malaysia, Western and Eastern Africa, tropical Asia, most Islands of both the Pacific and Carribean regions as well as in southern China and India. ${ }^{8,11}$

In terms of medicinal uses, various parts of this plant have also been known to be useful in traditional medicine for the treatment of asthma, boil, diarrhoea, gout, inflammations, rheumatism, tumors, ulcers and as a tonic..$^{12-15}$

Previous phytochemical studies on this plant revealed the presence of robinetin, chalcone, tanins, flavonoids, terpenoids, saponins, alkaloids, steroids, butin and flavonal ampelopsin, stigmasterol glucosides, oleanolic acid, echinocystic acid, sapogenins and many other bioactive phytoconstituents. ${ }^{16-23}$ Reports have shown that Adenanthera pavonina leaf and seed extract as well as isolated constituents possess analgesic, anti-inflammatory, antibacterial, antifungal, antioxidant, cytotoxic and blood pressure reducing activities. ${ }^{22,24-28}$ Although, the antioxidant activity of the bark extracts of Adenanthera pavonina had been reported. ${ }^{23}$ There has however been no documented report on the antimalarial and antioxidant activities of the seed extract of Adenanthera pavonina. Therefore, this study is primarily designed to determine the antimalarial and antioxidant activities of the seed extract of Adenanthera pavonina using in vitro and in vivo Plasmodium berghei infected mice model.

\section{MATERIALS AND METHODS}

\section{Plant material}

Adenanthera pavonina seeds were picked from the plant tree growing in the University of Ibadan Botanical garden and also from the University of Ibadan Staff Nursery and Primary School between 29th of August and 10th of November, 2011. The plant was identified at the Forestry Research Institute of Nigeria (FRIN), Jericho, Ibadan, Oyo State where a voucher specimen is preserved at the herbarium with a voucher number FHI 109007.
The fresh seeds of Adenanthera pavonina were cleaned and shade dried for about three weeks and blended with an electric blender to coarse powder. One thousand five hundred grams (1500 g) weight of the powdered sample was extracted with 3.2 litres of $98 \%$ methanol by cold maceration to obtain a crude methanolic extract. The crude methanol extract was concentrated with rotary evaporator and $38.4 \mathrm{~g}(2.56 \%$ yield $)$ of black oily crude extract was obtained. Thereafter, the crude extract was refrigerated at a temperature of $4^{\circ} \mathrm{C}$ before use.

\section{Experimental animals}

Male albino mice weighing between 20-25 g were obtained from the animal house of University of Ibadan, Ibadan and kept at the animal facility of the Malaria Research Laboratory, IMRAT, under standard condition. Mice were kept in cages at room temperature, fed with standard mouse cubes (Caps Feeds Nigeria Limited) and provided with access to clean drinking water ad libtum.

\section{Ethical consideration}

Experimental procedures and protocols used in this study conform to the "Guide to the care and use of animals in research and teaching" (NIH publications number 85-93 revised in 1985).

\section{Chemical and reagents}

Methanol, ethanol, dimethyl sulphoxide (DMSO), phosphate buffer, normal saline, 1,1- diphenyl-2picrylhydrazyl (DPPH), ascorbic acid, sodium hydroxide $(\mathrm{NaOH})(\mathrm{BDH}$, England), bovine serum albumin (BSA)(Sigma Chemical Co., USA), $\mathrm{CuSO}_{4}, 5 \mathrm{H}_{2} \mathrm{O}$ (BDH chemicals, England), potassium iodide (BDH Chemicals, England), xynenol orange, ammonium ferrous Sulphate, tetrahydraxosulphuric $\left(\mathrm{H}_{2} \mathrm{SO} 4\right)$, sorbitol, 30\% trichloroacetic acid (TCA), $0.75 \%$ thiobarbituric acid (TBA), 0.15M tris $-\mathrm{KCl}$, buffer (pH 7.4), $40 \mathrm{mg}$ GSH (Sigma Chemical Co., London), di-potassium hydrogen orthorphosphate, $\mathrm{K}_{2} \mathrm{HPO}_{4}$ (Hopkins and Williams, Ltd), $0.973 \mathrm{~g}$ of potassium di-hydrogen orthophosphate, $\mathrm{K}_{2} \mathrm{PO}_{4}$ (Hopkins and Williams Ltd), Ellman Reagent [5,5-dithiobis(2-nitrobenzoate) DTNB], 4\% sulphursalicyclic acid $\left(\mathrm{C}_{7} \mathrm{H}_{6} \mathrm{~S} .2 \mathrm{H}_{2} \mathrm{O}\right)$ were used for the three studies.

\section{Acute toxicity test}

The oral acute toxicity of the methanol extract was estimated in mice weighing 20-25 $\mathrm{g}$ by medium lethal dose described by. ${ }^{29}$ Mice were adminstered orally with graded doses ranging from 250 to $8000 \mathrm{mg} / \mathrm{kg}$. Negative control animals received $5 \%$ DMSO. Signs of toxicity and mortality in each group were observed for $24 \mathrm{~h}$.

\section{Antimalarial test in vivo}

The antimalarial activity of the methanol extract of Adenanthera pavonina was evaluated using a modification of 
the 4-day suppressive tests in vivo. ${ }^{30}$ Thirty-five male albino mice were randomly distributed into seven groups of five mice each. Each mouse was infected intraperitoneally $1 \times 10^{7}$ parasitized erythrocytes from an infected donor mouse. The day of infection was defined as day zero (D0), and subsequent days D1, D2, etc.

The infected mice were treated shortly after inoculation on day zero (D0) till day 2 or 3. Animals in groups 3-7 received graded doses of $\mathrm{AP}(100,200,400,600$ and 800 $\mathrm{mg} / \mathrm{kg}$ ) respectively. Groups 1 and 2 received chloroquine $(10 \mathrm{mg} / \mathrm{kg}$ dose $)$ and 1\% DMS0 respectively and served as controls. Parasite count was estimated by microscopic examination of Giemsa-stained thin smears prepared from tail snips of experiemtal animal on day 4 till 7 postinfection. Percentage chemosuppression of each dose was then calculated using this formula. Chemosuppression of parasite growth $=100-[$ (mean parasitemia treated $/$ mean parasitemia control) x 100] $]^{31}$ (Fidock et al., 2004). On day 7 , after making the last thin blood film, all surviving animals from each group were sacrificed and their blood samples were obtained for biochemical analysis.

Free radical scavenging activity using diphenyl 1,2-picryl hydrazyl (DPPH)

The scavenging activity of the ADP was determined according to the method described by (Silva et al., 2007) ) $^{32}$ with some modifications. The assay is an ethanol based assay.

Free radical scavenging is one of the mechanisms involved in antioxidant action, a good antioxidant (AH) is able to scavenge the DPPH free radical and retain its own stability as shown in the equation below. ${ }^{33}$

$$
\mathrm{DPPH}+\mathrm{AH} \rightarrow \mathrm{DPPH}-\mathrm{H}+\mathrm{A}
$$

Scavenging of DPPH free radical deterrnines the free radical scavenging capacity or the antioxidant potential of the test sample which shows its effectiveness, prevention, interception and repair mechanism against injury in a biological system. Serial drug dilutions of ADP and ascorbic acid ranging from 400 to $6.25 \mu \mathrm{g} / \mathrm{ml}$ and 40 to $0.63 \mu \mathrm{g} / \mathrm{ml}$ were prepared in a 96 -well plate respectively. Ethanol solution of DPPH $(0.04 \mathrm{mg} / \mathrm{ml})$ was added to each well of the 96-well plate and incubated in the dark for 30 mins. A blank control was also included in the 96-well plate. The change in colour (from deep-violet to yellow) was measured at $517 \mathrm{~nm}$ with a molecular device (SPECTRAmax, Molecular Devices, USA). Optical density count (OD) values were expressed as the percentage of the control. Percentage scavenging ability of the plant extract or standard drug in respect to the negative control well was calculated by the following formula. $\begin{aligned} & \text { Percentage } \\ & \text { scavenging }\end{aligned}=\frac{\text { Absorbanceof control }- \text { Absorbance of test }}{\text { Absorbance of control }} \times 100$

The plant extract/drug concentrations were plotted against percentage scavenging ability of plant extract or standard drug. Fifty percent (50\%) inhibitory concentration of plant extract/standard drug $\left(\mathrm{IC}_{50}\right)$ was determined using non linear regression.

The $\mathrm{IC}_{50}$ of the sample was compared with the standard, ascorbic acid.

Procedure for markers of oxidative stress and antioxidant defence system

\section{Biochemical assays}

The protein concentrations of the various samples were determined by means of the Biuret method as previously described ${ }^{34}$ with some modifications. For the in vivo study, $1 \mathrm{ml}$ ofthe blood plasma fractions of the supernatant was added to $9 \mathrm{ml}$ of distilled water to give a 1 in 10 dilutions for each of the samples. Three milliliter of Biuret reargent was added to $1 \mathrm{ml}$ of diluted sample in the 35 test tubes. The mixtures in both cases were incubated at room temperature for 30 minutes after which the absorbance was read with a spectrophotometer at $540 \mathrm{~nm}$ using distilled water as blank. The protein content of the samples were usually calculated from the standard curve using bovine serum albumin (BSA).

\section{Estimation of reduced glutathione (GSH)}

The method of Beutler and colleagues ${ }^{35}$ with some modifications were followed in estimating the level of reduced glutathione $(\mathrm{GSH})$. One $\mathrm{ml}$ of the serum was deproteinated by the addition of $1 \mathrm{ml}$ of $4 \%$ sulfosalicyclic acid. This was centrifuged at 4,000 rpm for 5 minutes. Thereafter, $0.5 \mathrm{ml}$ of the supernatant was added to 4.5 $\mathrm{ml}$ of Ellman reagent. A blank was prepared with $0.5 \mathrm{ml}$ of the diluted precipitating agent and $4.5 \mathrm{ml}$ of Ellman reagent. Reduced glutathione, GSH, is proportional to the absorbance at $412 \mathrm{~nm}$.

\section{Hydrogen peroxide generation}

Hydrogen peroxide was determined as described by Woff; 36 $2.5 \mathrm{mls}$ of phosphate buffer (PH 7.4) was added to $250 \mu \mathrm{l}$ of ammonium ferrous sulphate (AFS), $100 \mu \mathrm{l}$ of sorbitol, $100 \mu \mathrm{l}$ of Xylenol orange, $25 \mu \mathrm{l}$ of $\mathrm{H}_{2} \mathrm{SO}_{4}, 50 \mu \mathrm{l}$ of serum was vortexed and incubated at room temperature for a minimum of 30 mins. Absorbance was taken at $560 \mathrm{~nm}$.

\section{Lipid peroxidation}

The malondialdehyde level was calculated according to the method of Farombi and colleagues. ${ }^{37}$ Tris- $\mathrm{KCl}$ buffer, 1.6 
$\mathrm{ml}$ was mixed with an aliquot of $0.4 \mathrm{ml}$ of the serum sample to which $0.5 \mathrm{ml}$ of $30 \%$ trichloroacetic acid (TCA) was added. Then $0.5 \mathrm{ml}$ of $0.75 \%$ thiobarbituric acid (TBA) was added and placed in a water bath for $45 \mathrm{~min}$ at $80{ }^{\circ} \mathrm{C}$. This was then cooled in ice and centrifuged at 3000x g for 10 mins. The clear supernatant was collected and absorbance measured against a reference blank of distilled water at $532 \mathrm{~nm}$. Lipid peroxidation in units/mg protein or gram tissue was computed with a molar extinction coefficient of $1.56 \times 105 \mathrm{M}^{-1} \mathrm{Cm}^{-1}$

$\underset{\text { (units } / \mathrm{mg} \text { protein })}{\mathrm{MDA}}=\frac{\text { Absorbance } \times \text { volume of mixture }}{\mathrm{E}_{532 \mathrm{~nm}} \times \text { volume of sample } \times \text { mg protein }}$

\section{Statistical analysis}

All values were expressed as mean \pm SD. Data on antimalarial study was analyzed using the software Graphpad prism, version 4.0. A one way analysis of variance (ANOVA) using Newman Keuls Pro hoc test for analyzing data on antimalarial studies. Turkey's multiple comparison test was used to analyze the antioxidant study. Origin software was used to calculate the $\mathrm{IC}_{50}$ values for the in vitro antioxidant assay.

\section{RESULTS}

The methanol extract of Adenanthera pavonina exhibited an $\mathrm{LD}_{50}$ greater than $8000 \mathrm{mg} / \mathrm{kg}$ having shown no mortality at all the doses tested.

There was a statistical significant $(\mathrm{p}<0.001)$ and dose dependent antiplasmodial activity in mice infected with Plasmodium berghei (Table 1). The chemosuppression were $63.2 \%, 67.5 \%, 74.8 \%, 77.4 \%, 92.11 \%$ for $100,200,400$, $600,800 \mathrm{mg} / \mathrm{kg}$ doses respectively. The chemosuppression produced by the extract was significant $(\mathrm{p}<0.001)$ when compared with the control. At the dose of $800 \mathrm{mg} / \mathrm{kg}$, methanol seed extract of Adenanthera pavonina produced a chemosuppression of $92.11 \%$, which was higher than that of chloroquine $(88.73 \%)$ the reference drug, indicating a high antimalarial activity. However, on day 7 of post infection, the methanolic seed extract, showed recrudescence at all the tested doses but chloroquine being the standard drug still demonstrated 100\% chemosuppression by day 7 .

The in vitro antioxidant assay showed that the extract exerted a very low percentage inhibition of $57 \%$ at its highest concentration of $400 \mu \mathrm{g} / \mathrm{ml}$ which was not comparable to those of ascorbic acid with a percentage inhibition of $86 \%$ at its highest concentration of $40 \mu \mathrm{g} / \mathrm{ml}$ (Table 2). The $\mathrm{IC}_{50}$ value for the extract was found to be greater than $400 \mu \mathrm{g} / \mathrm{ml}\left(\mathrm{IC}_{50}>400 \mu \mathrm{g} / \mathrm{ml}\right)$ while ascorbic acid had an $\mathrm{IC}_{50}$ value of $1.20 \mu \mathrm{g} / \mathrm{ml}$.

The in vivo antioxidant assay, showed a marginal increase in plasma total proteins in the parasitized treated groups with the methanolic seed extract at doses of 100, 200 and 800 $\mathrm{mg} / \mathrm{kg}$, and CQ $(10 \mathrm{mg} / \mathrm{kg})$ and an increase at 400 and 600 $\mathrm{mg} / \mathrm{kg}$ compared to the parasitized untreated group, but did not show any statistical significant difference ( $p>0.05)$ (Table 3). There was a slight decrease in malondialdehyde levels in the parasitized treated groups with the methanolic seed extract at doses of 100, 200, 400, $800 \mathrm{mg} / \mathrm{kg}$ and CQ $(10 \mathrm{mg} / \mathrm{kg})$ and an increase at $600 \mathrm{mg} / \mathrm{kg}$ dose compared to the parasitized untreated group, but was not statistically significant $(\mathrm{p}>0.05)$ (Table 3$)$. There was also a marginal increase in hydrogen peroxide generation at doses of 600 , $800 \mathrm{mg} / \mathrm{kg}$, and CQ (10 mg/kg) and a marginal decrease at doses of 100,200 and $400 \mathrm{mg} / \mathrm{kg}$ in the parasitized treated groups with the methanolic seed extractcompared to the parasitized untreated group, but was not statistically significant $(p>0.05)$ (Table 3). There was also a marginal increase in glutathione levels in the parasitized treated groups with the methanolic seed extract of Adenanthera pavonina at doses of 100, 200, $600 \mathrm{mg} / \mathrm{kg}$, and CQ (10 mg/kg) compared to the parasitized untreated group, but was not statistically significant $(\mathrm{p}>0.05)$. However, there was a statistical significant decrease in glutathione levels $(\mathrm{p}<0.05)$ at doses of 400 and $800 \mathrm{mg} / \mathrm{kg}$ in the parasitized treated groups with the methanolic extract of Adenanthera pavonina compared to the parasitized untreated group (Table 3).

\begin{tabular}{|c|c|c|c|c|c|c|c|c|}
\hline \multirow[t]{2}{*}{ Treatment } & \multicolumn{2}{|c|}{ Day 4} & \multicolumn{2}{|c|}{ Day 5} & \multicolumn{2}{|c|}{ Day 6} & \multicolumn{2}{|c|}{ Day 7} \\
\hline & $\begin{array}{c}\text { \% Mean } \\
\text { parasitemia }\end{array}$ & $\%$ inhibition & $\begin{array}{c}\% \text { Mean } \\
\text { parasitemia }\end{array}$ & $\%$ inhibition & $\begin{array}{c}\text { \% Mean } \\
\text { parasitemia }\end{array}$ & $\%$ inhibition & $\begin{array}{c}\text { \% Mean } \\
\text { parasitemia }\end{array}$ & $\%$ inhibition \\
\hline ME 100 mg/kg & $4.23 \pm 2.51$ & 6.04 & $8.26 \pm 6.00^{*}$ & 63.2 & $13.3 \pm 13.4^{*}$ & 49.8 & $27.6 \pm 8.38$ & 0.00 \\
\hline ME $200 \mathrm{mg} / \mathrm{kg}$ & $2.03 \pm 2.65$ & 54.9 & $7.25 \pm 5.36^{*}$ & 67.5 & $11.3 \pm 6.64^{*}$ & 57.4 & $21.5 \pm 11.4$ & 18.9 \\
\hline ME $400 \mathrm{mg} / \mathrm{kg}$ & $4.09 \pm 1.66$ & 9.2 & $5.77 \pm 3.06^{*}$ & 74.2 & $6.06 \pm 5.98^{*}$ & 50.3 & $18.7 \pm 7.05$ & 29.5 \\
\hline ME 600 mg/kg & $1.97 \pm 1.98$ & 56.2 & $5.06 \pm 5.11^{*}$ & 77.4 & $8.74 \pm 10.1^{*}$ & 67.0 & $12.9 \pm 11.8$ & 51.3 \\
\hline ME 800 mg/kg & $1.70 \pm 3.35$ & 62.2 & $1.77 \pm 3.48^{*}$ & 92.1 & $15.9 \pm 5.79$ & 46.0 & $24.9 \pm 6.85$ & 0.001 \\
\hline $\mathrm{CQ} 10 \mathrm{mg} / \mathrm{kg}$ & $1.08 \pm 0.69$ & 760.0 & $2.53 \pm 3.40^{*}$ & 88.7 & $0.00^{*}$ & 100.0 & $0.00^{*}$ & 100 \\
\hline $1 \%$ DMSO & $4.50 \pm 2.64$ & - & $22.4 \pm 5.72$ & - & $28.5 \pm 11.3$ & - & $26.5 \pm 6.66$ & - \\
\hline
\end{tabular}

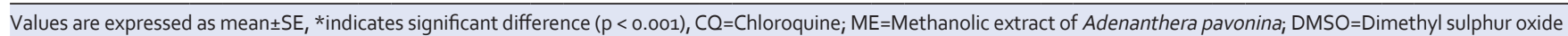




\begin{tabular}{|c|c|c|c|}
\hline $\begin{array}{l}\text { Conc of } \\
\text { Adenanthera } \\
\text { pavonina }(\mu \mathrm{g} / \mathrm{ml})\end{array}$ & $\%$ Inhibition & $\begin{array}{c}\text { Conc of } \\
\text { ascorbic } \\
\text { acid }(\mu \mathrm{g} / \mathrm{ml})\end{array}$ & $\%$ Inhibition \\
\hline 400 & $57 / 0$ & 40 & 86.0 \\
\hline 200 & 39.0 & 20 & 88.0 \\
\hline 100 & 24.0 & 10 & 92.0 \\
\hline 50 & 11.0 & 5 & 91.0 \\
\hline 25 & 4.70 & 2.5 & 90.19 \\
\hline 12.5 & 5.0 & 1.25 & 63.0 \\
\hline 6.25 & 2.0 & 0.625 & 33.0 \\
\hline
\end{tabular}

\begin{tabular}{|c|c|c|c|c|}
\hline $\begin{array}{l}\text { Groups } \\
(n=5)\end{array}$ & $\begin{array}{l}\text { Plasma } \\
\text { total } \\
\text { protein } \\
\text { (mg/dl) }\end{array}$ & $\begin{array}{c}\text { MDA } \\
\text { ( } \mu \mathrm{mol} / \mathrm{mg} \\
\text { protein) }\end{array}$ & $\begin{array}{c}\mathrm{H}_{2} \mathrm{O}_{2} \\
\text { generated } \\
(\mu \mathrm{mol} / \mathrm{mg})\end{array}$ & $\begin{array}{c}\text { Reduced } \\
\text { GSH } \\
(\mu \mathrm{g} / \mathrm{ml})\end{array}$ \\
\hline $\begin{array}{l}\text { Parasitized+ } \\
1 \% \text { DMSO }\end{array}$ & $17.9 \pm 1.8$ & $1.69 \pm 0.79$ & $0.39 \pm 0.03$ & $220.8 \pm 4.02$ \\
\hline $\begin{array}{l}\text { Parasitized+ } \\
\mathrm{CQ}(10 \mathrm{mg} / \mathrm{kg})\end{array}$ & $18.2 \pm 1.7$ & $1.47 \pm 0.48$ & $0.56 \pm 0.16$ & $225.4 \pm 2.1$ \\
\hline $\begin{array}{l}\text { Parasitized+ } \\
\text { ME (100 mg/kg) }\end{array}$ & $20.65 \pm 1.7$ & $1.18 \pm 0.96$ & $0.34 \pm 0.03$ & $223.5 \pm 1.3$ \\
\hline $\begin{array}{l}\text { Parasitized+ } \\
\text { ME }(200 \mathrm{mg} / \mathrm{kg})\end{array}$ & $18.9 \pm 1.9$ & $1.65 \pm 1.13$ & $0.37 \pm 0.07$ & $225.3 \pm 0.38$ \\
\hline $\begin{array}{l}\text { Parasitized+ } \\
\text { ME (400 mg/kg) }\end{array}$ & $17.9 \pm 1.4$ & $1.31 \pm 0.22$ & $0.44 \pm 0.08$ & $140 \pm 29.3^{*}$ \\
\hline $\begin{array}{l}\text { Parasitized+ } \\
\text { ME ( } 600 \mathrm{mg} / \mathrm{kg})\end{array}$ & $17.4 \pm 0.7$ & $2.35 \pm 1.40$ & $0.62 \pm 0.08$ & $198.7 \pm 12.0$ \\
\hline $\begin{array}{l}\text { Parasitized+ } \\
\text { ME (800 mg/kg) }\end{array}$ & $19.1 \pm 1.8$ & $1.44 \pm 0.48$ & $0.45 \pm 0.07$ & $168.7 \pm 1.47^{*}$ \\
\hline
\end{tabular}

Values are expressed as mean $\pm S D$, where $n=5 ; * P<0.05$ when compared to parasitized group. DMSO=Dimethyl Sulphur Oxide, ME=Methanolic extract of Adenanthera pavonina, MDA=Malondialdehyde, GSH=Reduced glutathione, $\mathrm{H}_{2} \mathrm{O}_{2}=$ Hydrogen peroxide

\section{DISCUSSIONS}

Based on Miller's recommendation, the extract was assumed to be safe. ${ }^{29}$ Invariably, the experimental doses used were relatively safe.

Agents with activity against Plasmodium berghei are known to have antimalarial activity. ${ }^{38}$ The methanolic extract of Adenanthera pavonina showed significant and dose dependent antiplasmodial activity $(63.2 \%-92.11 \%)$ as shown in Table 1, against Plasmodium berghei in mice at the doses of $100-800 \mathrm{mg} / \mathrm{kg}$. However, on day 7 , there was recrudescence of the malarial parasite in all the graded doses given to the experimental animals. This suggests that the methanolic seed extract of Adenantherapavonina could be a short acting drug and that on further purification and characterization of its active components, could be suitable as a prophylaxis drug to suppress malarial parasite. The occurence of recrudescence in the experimental animals after treatment, could be as a result of clearance of the crude extract from the systemic circulation through the urinary tract after being metabolized by the liver enzymes. The extract clearance from the systemic circulation would lead to increase in the parasite biomass in the body of the animals and thereby causing reinvasion and destruction of the erythrocytes by the malarial parasite. Report from a study, demonstrated that recrudescent infections are associated with worsened haematological outcomes. Also, that recrudescent infections occur sooner after treatment, leading to an overall increase in the incidence of infections. ${ }^{39}$ The methanolic seed extract of Adenanthera pavonina exhibited some degree of antimalarial activity, which may be attributed to its varying phytochemical constituents. These constituents may singly or in combination account for the pharmacological actions of the extract. Adenanthera pavonina had been reported to contain alkaloids, tannins, saponins and flavonoids, ${ }^{22}$ steroids and terpenoid. ${ }^{23}$ The presence of these secondary metabolites in Adenanthera pavonina, had been implicated in the antiplasmodial effects of some herbal medicines. ${ }^{40,41}$ Thus, the abundant presence of alkaloids and flavonoids in the methanolic extract of the plant, might have accounted for its high antimalarial activity. Although, the mechanism of action of this extract has not been elucidated; some plants are known to exert antiplasmodial activity either by causing red blood cell oxidation ${ }^{42}$ or by inhibiting protein synthesis, ${ }^{43}$ depending on their phytochemical constituents. The extract could have also, exerted its action through either of the two mechanisms mentioned above or by some other unknown mechanism. Thus, the mechanism of action still needs to be elucidated.

Furthermore, the in vitro antioxidant capacity of the plant extract was evaluated in DPPH based assay which is an extensively used assay to detect antioxidant activity of plants. Its violet colour dissappears in the presence of substances which can donate a hydrogen depending on the antioxidant activity. ${ }^{44}$ The in vitro study showed that the methanolic seed extract of Adenanthera pavonina is not a potent scavenger of DPPH free radical as shown in its $\mathrm{IC}_{50}>400 \mu \mathrm{g} / \mathrm{ml}$. This value is far more in excess of the $\mathrm{IC}_{50}$ of ascorbic acid that is $1.20 \mu \mathrm{g} / \mathrm{ml}$, which was used as the reference drug. Similarly, a high value, $\mathrm{IC}_{50} 390.33$ $\pm 2.78 \mu \mathrm{g} / \mathrm{ml}$ suggesting weak antioxidant activity, was reported for the bark extract of the plant when petroleum ether was used as the solvent for extraction. However, when ethyl acetate and methanol were used as solvents, high antioxidant activities $\left(\mathrm{IC}_{50}\right.$ value $8.72 \pm 0.11 \mu \mathrm{g} / \mathrm{ml}$ and $6.44 \pm 0.04 \mu \mathrm{g} / \mathrm{ml}$ respectively were obtained. ${ }^{23}$ A study reported that the bark extract of the plant had an $\mathrm{EC}_{50}$ of $58.68 \mu \mathrm{g} / \mathrm{ml}$ using petroleum ether, dichloromethane and ethanol $^{45}$ contrary to the earlier finding. ${ }^{23}$ Dec oction of the 
leaves of Adenantherapavonina and Thespesiapopulnea showed a very high antioxidant activity $(7.24 \pm 0.49 \mu \mathrm{g} / \mathrm{ml}) .{ }^{46}$ The difference in the antioxidant activity observed in this study and the previous study may be as a result of many factors such as season, age, intraspecies variation, soil, climate, methods used for extraction, and bioassay. ${ }^{47}$

Several studies have shown that the levels of total proteins in plasma decreases after infection with $P$. falciparum. Proposed reasons included the fact that the concentration of plasma proteins determine the colloid osmotic pressure of plasma and that this is influenced by the nutritional status, hepatic and renal function. ${ }^{48,49}$ Furthermore, malaria has an effect on all these functions an this results in decreased plasma total proteins. ${ }^{50}$ It is also well known that hepatic protein synthesis shifts during inflammation from albumin synthesis to the synthesis of proteins involved in the acute inflammatory response such as c-reactive proteins, coagulation factors, fibrinogen. ${ }^{51}$ In the present study, there was no statistical significant difference in total plasma proteins in the parasitized treated groups with the methanolic seed extract of Adenantherapavonina compared to the parasitized untreated group. This indicates that the extract is neither boosting the antioxidant defence system nor is it depleting it. This suggests that the extract may not have an antioxidant activity and so may be inducing stress in the animal and so supports the result from the in vitro studies. Increase in hydrogen peroxide generation has been known to mediate its effect through the formation of hydroxyl radical $(\mathrm{OH})$ which is a potent activator of lipid peroxidation. ${ }^{52}$ These hydroxyl radical rapidly reacts at first encounter with lipids, proteins and DNA, often causing molecular and cellular damage. ${ }^{53,54}$ The in vivo study shows no statistical significant difference in hydrogen peroxide generation in parasitized treated groups with the methanolic seed extract compared to the parasitized untreatedgroup. Although, one may not be able to account for the observed decrease in hydrogen peroxide generation in the parasitized untreated group compared to the marginal increase in $\mathrm{H}_{2} \mathrm{O}_{2}$ generation, observed in the parasitized treated groups with the methanolic seed extract at doses 200, 400, 600 and $800 \mathrm{mg} / \mathrm{kg}$ and then a decrease in $\mathrm{H}_{2} \mathrm{O}_{2}$ generation at the dose of $100 \mathrm{mg}$ $\mathrm{kg}$; but may associate this inconsistency in activity of the methanolic seed extract, to the result of the in vitro study that shows that it has no antioxidant effect. Hence, further studies may still explain this findings. Increase in malondialdehyde (MDA) levels is an indication of lipid peroxidation, hence, oxidative stress. Malondialdehyde which has been used in various biochemical assay to monitor the extent of peroxidative damage in cells, showed no statistical significant difference $(p>0.05)$ in the parasitized treated groups compared to the parasitized untreated group. Hence, the marginal decrease in MDA levels observed at doses 100, 200, 400 and $800 \mathrm{mg} / \mathrm{kg}$ may not be associated with the effect of the extract but may be as a result of host way of adapting to the stressed condition. Contrary to this, at dose $200 \mathrm{mg} / \mathrm{kg}$, there was an increase in MDA levels, although statistically not significant; may still suggest that the extract may not possess some antioxidant activity. Glutathione (GSH) is an excellent and potent endogenous antioxidant, which by scavenging various types of reactive radicals protects the cell from oxidative insults. ${ }^{55}$ On encounter with reactive radicals, GSH stores may be depleted, leaving the cells with compromised antioxidant defense system against 'oxidant-induced injury'. In the present study, there was a statistical and significant decrease $(\mathrm{p}<0.05)$ in glutathione levels in the parasitized treated groups at doses 400 and $800 \mathrm{mg} / \mathrm{kg}$ compared to the parasitized untreated group. This indicates that the animal may be under stress since glutathione levels are been significantly depleted. Therefore, the extract may actually be inducing stress in the animal. The marginal increase at doses of 100,200 and $600 \mathrm{mg} / \mathrm{kg}$ was not statistically significant.

\section{CONCLUSION}

Adenanthera pavonina while exhibiting antimalarial activity may not possess significant antioxidant property.

\section{ACKNOWLEDGEMENTS}

Dr Sola Gbotosho is appreciated for providing us access to the malaria research laboratory. Mr. Remi Aladeokin offered some technical assistance.

\section{REFERENCES}

1. Bowman WC, Rand MJ: Textbook of Pharmacology, 2nd edition. Blackwell Scientific Publications 1980 pp. 36: 1-36.12.

2. Penn RG: Pharmacology. Concise Medical Textbooks. London 1974; 276.

3. Pabon A, Carmona J, Burgos LC and Blair S. Oxidative stress in patients with non-complicated malaria. Clin Biochem 2003; 36:71-78.

4. Clark IA, Chaudhri $C$ and Cowden WB. Some roles of free radicals in malaria. Free Radic Biol and Med 1989; 6:315-321.

5. Halliwell B, Aeschbach R, Lolliger $\mathrm{J}$ and Aruoma OI. The characterization of antioxidants. Food Chem Toxicol 1995; 33:601-617.

6. Behera BC, Verma N, Sonone A and Makhija U. Determination of antioxidative potential of lichen Usnea ghattensis in vitro. LWT 2006; 39:80-85.

7. Dean RT and David MJ. Reactive species and there accumulation on radical damaged proteins. Trends Biochem Sci 1993; 18:437441.

8. Balogun AM and Fetuga BL. Fatty acid composition of seed oils of some members of the Leguminosae Family. Food Chem 1985; 17(3):175-182. 
9. Burkill IH. A dictionary of the economic products of the Malay, peninsula. 2nd ed, Volume I.A-H Government of Malaysia and Singapore. KualaLumpur. Malaysia. 1240 p. 1966.

10. Bouquet $A$ and Debray M. Medicinal Plants in Ivory Coast. Document Orstom France. 1974; 32: 1-4.

11. GRIN Databases: USDA, ARS, National Genetic Resources Program. Germplasm Resources Information Network (GRIN) [Online Database], National Germplasm Resources Laboratory, Beltsville, Maryland 2009.

12. Watt JM, Breyer-Brandwijk MG. The medicinal and poisonous plants of Southern and Easthern Africa, 2nd Edn and $S$ Livingstone Ltd: London. 1962.

13. Kirtikar KR, Basu BD. Indian Medicinal Plants (2nd Edn.), International Book Distributors, India, 1981: 1710.

14. Burkill HM. The useful plants of West Tropical Africa.Vol 2. Royal Botanical Gardens, Kew, London. 1994.

15. Ghani A. Medicinal Plants of Bangladesh (Chemical Constituents and uses). 2nd Ed. Published by Asiatic Society of Bangladesh;. Dhaka-1000, Bangladesh 2003; 331-332.

16. Neerja Y, Gopal M and Nigam SK. Triterpenoids of Adenanthera pavonina Bark. Planta Med 1976; 29: 176-178.

17. Chandra S, Verma $M$ and Saxena $H$. Triterpenoids of Adenanthera pavonina root. Int J Crude Drug Res 1982; 20:165-167.

18. Yeoh HH, Wee YC and Watson L. Systematic variation of leaf amino acid compositions of leguminous plants. Phytochemistry 1984; 23(10):2227-2229.

19. Mesbah UA and Ataur R. Md, Tabassum R, Nahar K. Chemical constituents of the leaves of Adenanthera pavonina L. Journal of the Bangladesh Chemical Society, 2002; 15(2):194-199.

20. Shaiq AM, Ahmed F, Azhar I and Pervez MK. Pavinin: A new five membered lactone from Adenanthera pavonina L. (Mimoaceac). Natural Product Research 2005; 19(1):37-40.

21. Enuo $Y$ and Shishan PY. Studies on chemical constituents from stems and leaves of Adenanthera pavonina L. Zhongguo Zhongyao Zazhi 2007; 32(20):2135-2138.

22. Adedapo ADA, Osude YO, Adedapo AA, Moody JO, Adeagbo AS, Olajide OS, et al. Blood Pressure Lowering Effect of Adenanthera Pavonina seed extract on normotensive rats. Records of Natural Products 2009; 3(2):82-89.

23. Ara A, Saleh-e-In MM, Ahmed NU, Ahmed M, Hashern MA and Bachar SC. Phytochemical screening, Analgeisc Antimicrobial and Antioxident Activities of Bark Extracts of Adenantera Pavonina L. (fabaceae). Advances in Natural and Applied Sciences 2010; 4(3):352-360.

24. Nigam SK, Misra G and Mitra CR. Stigmasterol glucosides a constituents of Adenanthera pavonina seed and leaf. Planta Med 1973; 23(2):145-148.

25. Olajide OA, Echianu CA, Adedapo ADA and Makinde JM. Antiinflammatory studies onAdenanthera pavonina seed extract. Inflammopharmacol 2004; 12(2):196-202.

26. Jayasinghe PKIDE, Bandara BMR, Ekanayaka BWMA and Thevanesam $V$. Screening for antimicrobial activity of Acronychia pedunculata (Ankenda) and Adenanthera pavonina (Madatiya) against bacteria causing skin and wound infections in humans. In Proceedings of the Peradeniya University Research Sessions-Sri Lanka 2006; 11:105.

27. Rodrigo SK, Jayasingha ULB and Bandara BMR. Antifungal, antioxidant and cytotoxic activity of Acronychia pedunculata and Adenanthera pavonina. In Proceedings of the Peradeniya University Research Session Sri Lanka 2007; 12(1):94-95.

28. Mayuren $\mathrm{C}$ and llavarasan R. Anti-inflamatory activity of ethanolic leaf extracts from Adenanthera pavonina (L) in Rat. Pharmacognosy 2009; 1(2):125-128.
29. Miller LC and Tainter MC. Estimation of the LD50 and its errors by means of logarithmic probit graph paper. Proc Soc Exp Biol Med 1944; 57:261-264.

30. Peters W. Competitive relationship between Eperythrozoon coccoides and Plasmodium berghei in the mouse. Exp Parasitol 1965; 16:158-166.

31. Fidock DA, Rosenthal PJ, Croft SL, Brun R and Nwaka S. Antimalarial drug discovery: Efficacy models for compound screening. Nature Reviews 2004; 3:509-519.

32. Silva EM, Souza JNS, Rogez $H$, Rees JF and Larondelle Y. Antioxidant activities and polyphenolic contents of fifteen selected plant species from the Amazonian region. Food Chem 2007; 101:1012-1018.

33. Gordon $\mathrm{MH}$. Measuring antioxidant activity. In: J. Pokomy, N. Yanishlieva and M. H. Gordons (Eds.), Antioxidant in food: Practical applications Woodhead Publishing Ltd, Cambridge; 2001;71-84.

34. Gornal AG, Bardwil GS and David MM. Determination of serum proteins by the mean of the Biuret reactions. Biochemistry 1949; 177:751-766.

35. Beutler E, Duron $\mathrm{O}$ and Kellin BM. Improved method for the determination of blood glutathione. Journal of Laboratory and Clinical Medicine 1963; 61: 882-890.

36. Woff SF. Ferrous ion oxidation in the presence of ferric ion indicator xylenol orange for measurement of hydrogen peroxides. Methods in Enzymology 1994; 233:182-189.

37. Farombi EO, Nwankwo JO, Wara SH, Odutola B and Emerole GO. Chloramphenicol and ampicillin-induced changes in rat hepatic esterase and amidase activities. Biology and Science Representation 2000; 20:13-19.

38. Calvalho LH, Brando MGL, Santos-filho D, Lopes JLC and Krettli AU. Antimalarial of crude extracts from Brazilian plants studies in vivo in Plasmodium berghei infected mice and invitro against Plasmodium falciparum in culture. Brazilian Journal of Medical and Biological Research 1991; 24:1113-1123.

39. Shaukat AM, Gilliams EA, Kenefic LJ, Laurens MB, Dzinjalamala FK, Nyirenda OM, et al. Clinical manifestations of new versus recrudescent malaria infections following antimalarial drug treatment. Malar J 2012; 11: 207.

40. Philipson JO and Wright CW. Antiprotozoal compound from plants sources. Planta Med 1990; 57:553-559.

41. Christensen SB and Kharazmi A. Antimalarial natural products. Isolation, characterization and biological properties. In: Tringali C, editor. Bioactive compounds from natural sources. Isolation, characterization and biological properties. London: Taylor and Francis 2001; 379-432.

42. Etkin NL. Antimalarial plants used by Hausa in northern Nigeria. Tropical Doctor 1997; 27:12-16.

43. Kirby GC, O'Neil MJ, Philipson JD and Warhurst DC. Invitro studies on the mode of action quassionoids with activity against chloroquine-resistant Plasmodium falciparum. Biochemistry Pharmacology 1989; 38:4367-4374.

44. Molyneux P. The use of the stable free radical diphenylpicrylhydrazyl (DPPH) for estimating antioxidant activity. Songklanakarin J Sci Technol 2004; 26:211- 219.

45. Ramli S, Bunrathep S, Tansaringkarn $\mathrm{T}$ and Ruangrungsi $\mathrm{N}$. Screening for free radical scavenging activity from ethanolic extract of mimosaceous plants endemic to Thailand. J Health Res 2008; 22:55-59.

46. Silva IK and Soysa P. Evaluation of Phytochemical Composition and antioxidant capacity of a decoction containing Adenanthera pavonina $L$ and Thespesia populnea $L$. Pharmacognosy Magazine 2011; 7:193-199.

47. Muregi FW, Chhrabra SC, Njagi EN, Lang'at-Thoruwa CC, Njue WM, Orago ASS, et al. In vitro antiplasmodial activity of some 
plants used in Kissi, Kenya against malaria and their chloroquine potentiating effects. J Ethnopharmacol 2003; 84:235-239.

48. Adebisi SA, Soladoye AQ, Adekoya D and Odunkanmi OA. Serum protein fractions of Nigerian with plasmodium infection: ILRON Experience 1998 pp. 82-84.

49. Adeosun OG, Oduola T, Akanji BO, Sunday AM, Udoh SJ and Bello IS. Biochemical alteration in Nigerian children with acute falciparum malaria. African Journal of Biotechnology 2007; 6:881-885.

50. Chang FC and Herzog B. Burn morbidity: A follow-up syudy of physical and psychological disability. Ann Sur 1976; 183:34-37.

51. Mac SRNM and Whaley K. Muirs textbook of pathology. Thirteen edition Arnold-Hodderline Group. London. Co-published in USA by Oxford University Press, Inc, New York. 2001.

52. Teo S, Pohl L and Hapert J. Production of superoxide anion-radicals during the oxidative metabolism of aminochloramphenicol. Biochemical Pharmacology 2009; 35:4586- 28.

53. Imlay JA and Linn S. DNA damage and oxygen radical toxicity. Science 1988; 240:I302-1309.

54. Halliwell B and Gutteridge JMC. Role of free radicals and catalytic metal ions in human disease: an overview. Methods Enzymology 1990; 186:1-85.

55. Hayes JD and McLellan LI. Glutathione and glutathione dependent enzymes represent a co-ordinately related defence against oxidative stress. Free Radical Research 1999; 31:273300.

\section{Authors Contribution:}

ADA - conceived the study; ADA, JNO, AAA - designed the entire study; AAA and JOM - anchored the extraction; OOA - contributed to the antimalarial aspect while; AAO and OA - contributed to the antioxidant aspect; JNO - with the supervision of other authors conducted the study and produced the first draft. All authors read, edited and contributed to the manuscript; ADA - worked on the final manuscript. 